\title{
ICP-AES Determination of Trace Metallic Elements in Plutonium Samples Containing Sizeable Amounts of Americium
}

\author{
A. Sengupta, V.C. Adya, Mithlesh Kumar, S.K. Thulasidas, S.V. Godbole*, and V.K. Manchanda \\ Radiochemistry Division, Bhabha Atomic Research Centre, Trombay, \\ Mumbai - 400 085, India
}

\begin{abstract}
During trace metallic assay of plutonium (Pu)-based fuel samples by inductively coupled plasma atomic emission spectrometry (ICP-AES), the regular procedure involves chemical separation of the major $\mathrm{Pu}$ matrix by solvent extraction using 30\% Tri-n-butyl phosphate, TBP/ $/ \mathrm{CCl}_{4} / 4 \mathrm{M} \mathrm{HNO}$, followed by the determination of trace metals in the raffinate by ICP-AES. During this process, americium (Am) follows the chemistry of trace metals and is present in the raffinate along with the analytes of interest. Since Am is a multielectron system rich in emission spectra, its inevitable presence in the sample may lead to overestimation of several trace elements due to its spectral interference.

The present investigations involved identification of analytical lines for the majority of trace elements free from Am interference using a high resolution ICPAES spectrometer. It also involved development of an analytical method for the simultane-
\end{abstract}

\section{INTRODUCTION}

Trace metal characterization of nuclear fuel materials is an integral part of quality assurance programs for nuclear fuel fabrication.

Amongst various trace metals, specifications for elements such as $\mathrm{B}, \mathrm{Cd}$, and rare earths with very high neutron absorption cross sections are quite stringent. In order to achieve desired detection limits for

\footnotetext{
*Corresponding autbor.
}

E-mail: svgod@barc.gov.in ous determination of Am by ICPAES and establishing correction factors for its spectral interference on other analytes as required. Based on these investigations, an analytical method was developed for ICP-AES for the determination of trace elements in Pu samples containing sizeable amounts of Am. The performance of the analytical method was evaluated by analyzing synthetic samples of Pu containing significant amounts of Am. These studies revealed that there is no appreciable contribution from the spectral interference of Am up to $300 \mu \mathrm{g} / \mathrm{mL}$ for analytical channels identified for the analytes using a high-resolution spectrometer. Using the analytical method developed in the present work, 25 trace elements in plutonium samples could be determined after separation of plutonium by $30 \% \mathrm{TBP} / \mathrm{CCl}_{4} / 4 \mathrm{M} \mathrm{HNO}_{3}$ with the lower quantification limits of $0.1 \mu \mathrm{g} / \mathrm{mL}$ for critical elements (B, Cd, Dy, Eu, Gd, Sm, etc.) and $5 \mu \mathrm{g} / \mathrm{mL}$ for other common impurities with a precision of $2 \%$ RSD in the presence of Am.

trace metals using emission spectrometric methods for quality assurance, it is necessary to separate the matrix from these analytes, thereby reducing the spectral interference from the major matrix (1-9).

In particular, rare earth elements are generally determined after their chemical separation from Pu-based fuels because of their stringent specification limits $(1,2)$. In these separation procedures in the raffinate-containing analytes, major matrix elements are reduced to the level of $<20 \mu \mathrm{g} / \mathrm{mL}$ to avoid spec- tral interference. However, ${ }^{241} \mathrm{Am}$ is invariably present in these samples and its content depends on the burn-up of the irradiated fuel and age of the separated $\mathrm{Pu}$ sample. Typically, about $50 \mathrm{mg}$ of ${ }^{241} \mathrm{Am}$ is produced from about $1 \mathrm{~g}$ of $\mathrm{Pu}$ generated from pressurized heavy water reactors (PHWR) per year. Chemical separation procedures followed for the removal of $\mathrm{Pu}$ for the determination of rare earths generally results in the presence of Am in the analyte stream. The presence of Am along with rare earths can lead to inaccurate overestimation of these elements due to its rich emission spectra $(10,11)$.

Claudon et al. (12) reported different atomic emission lines for Am with their relative intensity using ICP-AES of moderate resolution (0.02 nm). Different authors (5-20) have determined rare earth elements using ICP-AES/MS (inductively coupled plasma emission spectrometry/mass spectrometry) after separation using high performance liquid chromatography (HPLC), liquid chromatography (LC), and ion exchange resins to avoid any erroneous analytical results due to mutual spectral interference of rare earth elements. Mazzucotelli et al. (13) tried to understand the spectral interference of common elements, e.g., Li, K, $\mathrm{Na}$, and $\mathrm{Ca}$, on rare earth elements. Daskalova et al. (14) reported the mutual interference of rare earth elements by ICP-AES. To date there is limited data available in the literature to understand the spectral interference of Am on common impurities and rare earth elements (Dy, Gd, Eu, Sm) which is of great importance in chemical quality 
assurance programs related to nuclear fuel fabrication (21).

In the present work, investigations were carried out to develop analytical methods for the determination of trace metallic constituents in Pu-based samples containing Am and using ICP-AES analysis. The investigations involved identification of interference-free analytical lines for the simultaneous determination of Am and the spectral interference of Am on the analytical lines of all trace metallic constituents. In order to carry out this study, high purity Am was one of the primary requirements. In the course of these investigations, a method for obtaining high purity Am from the analytical waste was developed (15) and the purity of Am thus obtained was ascertained using ICPAES and neutron activation analysis. Required spectrometric investigations were carried out for the development of a methodology for trace metal assay of Pu-based samples.

\section{EXPERIMENTAL}

\section{Instrumentation}

All of the atomic emission spectrometric studies were carried out using a Jobin-Yvon Ultima high resolution ICP-AES (22). It has the practical resolution of $\leq 0.005 \mathrm{~nm}$ and a spectral range of $200-800 \mathrm{~nm}$. The specifications and operating conditions of the instrument are listed in Table I.

\section{Reagents and Standard Solutions}

Rare earth elements and other common impurity standard solutions were prepared from high purity solutions (E. Merck, Darmstadt, Germany) by suitable dilutions with $0.5 \mathrm{M} \mathrm{HNO}_{3}$. Suprapur ${ }^{\circledR}$ (E. Merck) $\mathrm{HNO}_{3}$ and quartz double- distilled water were used for preparing $0.5 \mathrm{M} \mathrm{HNO}_{3}$. Tri-nbutyl phosphate (TBP) was procured from Koch-Light Laboratories Pty. Ltd., Johannesburg,
South Africa. The calibration plots for each analyte were obtained by using multiple standards having analyte concentrations in the $0-100 \mu \mathrm{g} / \mathrm{mL}$ range. High purity Am stock solutions were prepared in our laboratory from analytical waste after the three-step separation procedure was used. Analytical waste contained uranium, iron, sodium, and calcium as major constituents along with milligram amounts of americium. Separation and purification was accomplished by using a three-stage separation procedure involving solvent extraction methods using (a) U-separation by 30\% Tri-n-butyl phosphate (TBP) in n-dodecane, (b) Fe and Na separation by $0.1 \mathrm{M} N, N_{,} \mathrm{N}^{\prime}, \mathrm{N}^{\prime}$ tetraoctyldiglycolamide (TODGA) $+0.5 \mathrm{M}$ di-hexyl octanamide (DHOA) in ndodecane and Ca separation by octyl phenyl-N,N-diisobutyl carbamoylmethyl phosphine oxide (CMPO) column chromatographic extraction (15). From the stock solution, different concentrations of Am in the $0.05-100 \mu \mathrm{g} / \mathrm{mL}$ range were prepared using proper dilutions with $0.5 \mathrm{M} \mathrm{HNO}_{3}$. Blank correction was carried out using $0.5 \mathrm{M}$ $\mathrm{HNO}_{3}$.

\section{RESULTS AND DISCUSSION}

The element ${ }^{241} \mathrm{Am}$, which is invariably present in Pu-based fuel samples due to the $\beta$ decay of ${ }^{241} \mathrm{Pu}$, follows the chemistry of analytes like rare earth elements during the separation of the Pu matrix by solvent extraction using TBP as an extractant. Consequently, the presence of appreciable amounts of Am in raffinate along with other analytes can lead to spectral interference during trace metallic impurity analysis of Pu-based samples by ICPAES due to its line-rich emission spectra $(10,11)$. Since it is cumbersome to prepare high purity spectroscopy-grade Am (23), there is very little literature available on the spectral interference of Am on concomitant analytes having stringent

TABLE I

HR-ICP-AES Specifications and Operating Conditions

\begin{tabular}{lr}
\hline Spectrometer & Model ULTIMA HR-ICP-AES \\
\hline Optical design & 1m Czerny Turner \\
Grating & Holographic, ion-etched optical grating - two \\
Groove density & 2400 grooves/mm, 4320 grooves $/ \mathrm{mm}$ \\
Grating size & $110 X 110 \mathrm{~mm}$ \\
Wavelength range & $120-800 \mathrm{~nm}$ \\
Band pass & $0.0023 \mathrm{~nm}$ from $120-340 \mathrm{~nm}$ \\
Thermal regulation & $0.0046 \mathrm{~nm}$ from $340-800 \mathrm{~nm}$ \\
RF Generator & Controlled to $30 \pm 1{ }^{\circ} \mathrm{C}$ \\
\hline Frequency & $40.68 \mathrm{MHz}$ \\
Oscillator & $27.12 \mathrm{MHz}$ \\
Pump & Dual channel $(12 \mathrm{roller})$ \\
Nebulizer & Pneumatic and concentric \\
Operating Conditions & $13 \mathrm{~L} / \mathrm{min}$ \\
Ar plasma flow & $10 \mathrm{~s}$ \\
Integration time & $<10 \mathrm{~W}$ \\
Reflected power & $1 \mathrm{~mL} / \mathrm{min}$ \\
Sample rate & \\
\hline
\end{tabular}


specification limits for Pu-based fuel samples. In our laboratory, high purity Am was obtained after using the three-step separation procedure (15) to study the spectral interference of Am on the trace metals and to arrive at correction factors due to the spectral interference of Am on the line measurements of the analytes. However, since the correction factor depends on the concentration of interfering elements, interference-free analytical lines, if possible, were required to be chosen for the accurate and precise determination of Am. The following steps were undertaken in the present study: (a) Determination of Am by ICP-AES; (b) spectral interference of Am on the regularly used analytical lines of concomitant analytes, and (c) validation of the methodology.

\section{Determination of Am by ICP-AES}

Claudon et al. (12) reported some of the Am emission lines with their relative intensities and spectral interference in the presence of $\mathrm{U}$ and $\mathrm{Pu}$. In the present studies, two of these Am lines, i.e., at $283.236 \mathrm{~nm}$, the most intense line of Am (see Figure 1), and 408.930 $\mathrm{nm}$, were investigated for their linear estimation range and the spectral interference from concomitant analyte elements in the raffinate obtained after chemical separation of Pu using the solvent extraction procedure with $30 \% \mathrm{TBP} / \mathrm{CCl}_{4} / 4 \mathrm{M}$ $\mathrm{HNO}_{3}$. Table II lists the calibration data for the Am analytical lines. Figures 2 and 3, respectively, show the linear calibration curves for these analytical lines obtained for Am using Am solutions with concentrations ranging from 0.5 to $100 \mu \mathrm{g} / \mathrm{mL}$. It was found that in both cases Am could be determined simultaneously by ICP-AES up to $100 \mu \mathrm{g} / \mathrm{mL}$ of Am with an RSD of $~ 2 \%$. In order to validate the analytical method, synthetic samples were analyzed by using ICP-AES and radiometric methods. The results obtained by ICP-AES were in good agreement with the radiometric determinations (Table III). Spectral interference from concomitant analytes on the identified lines of Am were studied using $1000 \mu \mathrm{g} / \mathrm{mL}$ concentrations of the corresponding elements. It was observed that for the Am analytical lines at $283.236 \mathrm{~nm}$ and $408.930 \mathrm{~nm}$, the contributions from Cr, Dy, Eu, Fe, Gd, and Sm were negligibly small (Table IV) and both lines can be used for the ICP-AES determination of Am (Table V).

\section{Spectral Interference of Am on Regularly Used Analytical Lines of Concomitant Analytes}

To develop the methodology for trace metallic impurity analysis by ICP-AES for Pu-bearing samples containing Am, the most important step is to study the spectral interference of Am on the analytes having stringent specification limits for $\mathrm{Pu}-$ based fuels. Using $100 \mu \mathrm{g} / \mathrm{mL}$ of high purity Am solution, spectral interference studies were carried out. For distinguishing the apparent concentration due to the spectral interference from the impurity content in purified Am, more than one analytical line was chosen for each analyte for their determination. The variation in estimated value in purified Am for the given element with the use of its different analytical channels was construed to be due to spectral interference, while nearly constant estimation using different analytical channels was interpreted as being due to its presence in purified Am as an impurity. The analytical line providing lowest concentration is least interfered

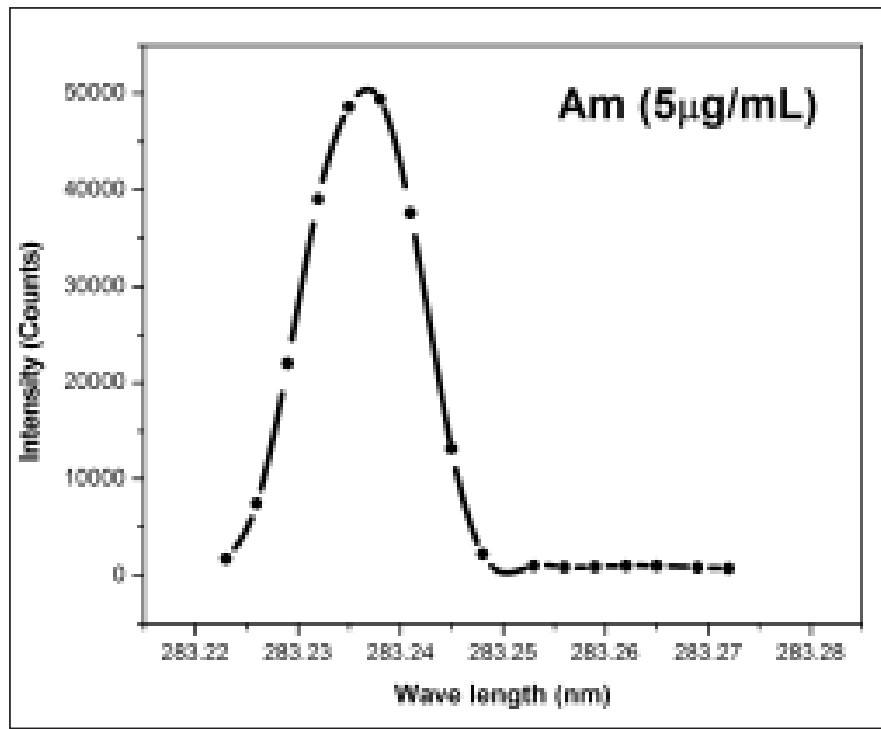

Fig. 1. Emission profile of Am (283.236 nm) line.
TABLE II Calibration Data for Am Analytical Lines

\begin{tabular}{lcc}
\hline Americium lines $(\mathrm{nm})$ & 283.236 & 408.930 \\
Slope (counts $\mu \mathrm{g} / \mathrm{mL})$ & 10899.59 & 3660.31 \\
Regression coefficient $(\mathrm{R})$ & 0.9999 & 0.9997 \\
\hline
\end{tabular}

TABLE III

ICP-AES Determination of Am

\begin{tabular}{ccc}
\hline $\begin{array}{c}\text { Conc. of Am } \\
\text { by Radiometry } \\
(\mu \mathrm{g} / \mathrm{mL})\end{array}$ & $\begin{array}{c}\text { Using 283.236 nm } \\
\text { line of Am } \\
(\mu \mathrm{g} / \mathrm{mL})\end{array}$ & $\begin{array}{c}\text { Using } 408.930 \mathrm{~nm} \\
\text { line of Am } \\
(\mu \mathrm{g} / \mathrm{mL})\end{array}$ \\
\hline 0.5 & $0.5 \pm 0.04$ & $0.43 \pm 0.04$ \\
5.0 & $5.4 \pm 0.5$ & $5.3 \pm 0.5$ \\
10.0 & $10.3 \pm 1$ & $10.6 \pm 1$ \\
20.0 & $20.8 \pm 2$ & $21 \pm 2$ \\
100 & $108 \pm 5$ & $106 \pm 5$ \\
\hline
\end{tabular}






Fig. 2. Calibration curve for Am 283.236 nm line.

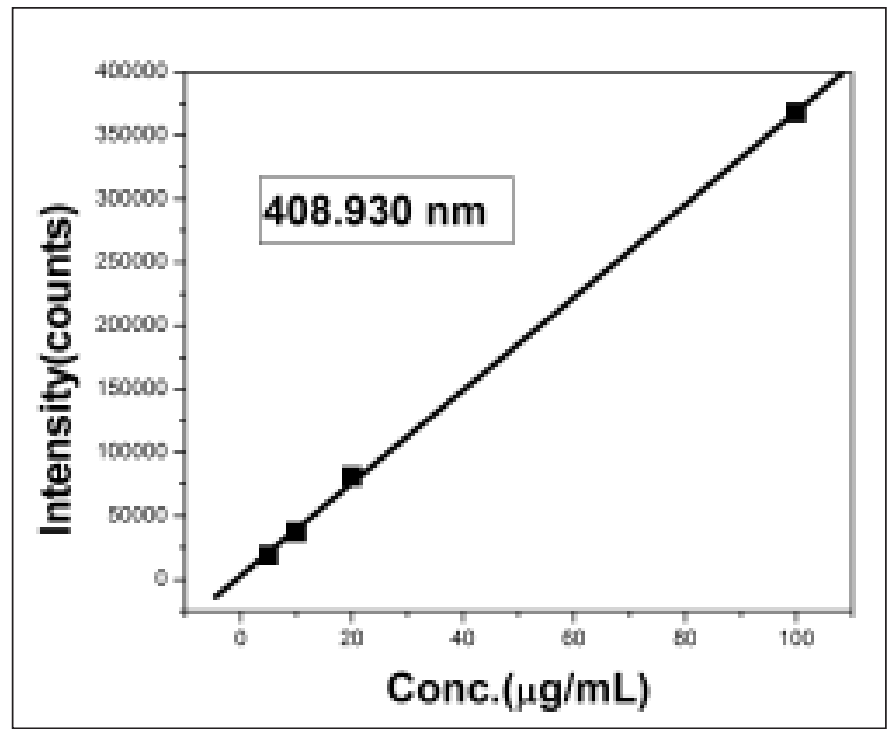

Fig. 3. Calibration curve for Am $408.930 \mathrm{~nm}$ line.
TABLE IV

Interference of Other Analytes on Am 283.236 nm Line

\begin{tabular}{ccccc}
\hline Element & $\begin{array}{c}\text { Am Analytical } \\
\text { Line } \\
(\mathrm{nm})\end{array}$ & $\begin{array}{c}\text { Concentration } \\
\text { Tested } \\
(\mu \mathrm{g} / \mathrm{mL})\end{array}$ & $\begin{array}{c}\text { Contribution } \\
\text { on Am Line } \\
(\mu \mathrm{g} / \mathrm{mL})\end{array}$ & $\begin{array}{c}\text { Correction } \\
\text { Factor }\end{array}$ \\
\hline $\mathrm{Cr}$ & 283.236 & 1000 & $<0.05$ & - \\
$\mathrm{Dy}$ & & 1000 & $<0.05$ & - \\
$\mathrm{Eu}$ & & 1000 & $<0.05$ & - \\
$\mathrm{Fe}$ & & 1000 & $<0.05$ & - \\
$\mathrm{Gd}$ & & 1000 & 0.265 & $2.65 \times 10^{-4}$ \\
$\mathrm{Sm}$ & & 1000 & $<0.05$ & - \\
\hline
\end{tabular}

TABLE V

Interference of Other Analytes on Am $408.930 \mathrm{~nm}$ Line

\begin{tabular}{ccccc}
\hline Element & $\begin{array}{c}\text { Am Analytical } \\
\text { Line } \\
(\mathrm{nm})\end{array}$ & $\begin{array}{c}\text { Concentration } \\
\text { Tested } \\
(\mu \mathrm{g} / \mathrm{mL})\end{array}$ & $\begin{array}{c}\text { Contribution } \\
\text { on Am Line } \\
(\mu \mathrm{g} / \mathrm{mL})\end{array}$ & $\begin{array}{c}\text { Correction } \\
\text { Factor }\end{array}$ \\
\hline $\mathrm{Dy}$ & 408.930 & 1000 & 1.68 & $1.68 \times 10^{-3}$ \\
$\mathrm{Eu}$ & & 1000 & 0.18 & $1.8 \times 10^{-4}$ \\
$\mathrm{Gd}$ & & 1000 & 3.51 & $3.51 \times 10^{-3}$ \\
$\mathrm{Sm}$ & & 1000 & 0.173 & $1.73 \times 10^{-4}$ \\
\hline
\end{tabular}

and, in general, the analytical lines showing the presence of elements below the limits of quantification were chosen as interference-free. Table VI shows that for the elements $\mathrm{Ag}, \mathrm{Al}, \mathrm{Ca}, \mathrm{Co}, \mathrm{Cr}, \mathrm{Dy}, \mathrm{Eu}, \mathrm{Fe}, \mathrm{Mn}$, $\mathrm{Na}, \mathrm{Ni}, \mathrm{Pb}$, and $\mathrm{Sm}$, there was no contribution of up to $100 \mu \mathrm{g} / \mathrm{mL}$ of Am on their respective analytical lines. The results of the determination of trace elements in the purified $\mathrm{Am}($ at $100 \mu \mathrm{g} / \mathrm{mL}$ ) using more than one analytical channel of the corresponding elements are listed in Table VII. Gd has analytical lines at $310.050 \mathrm{~nm}, 335.048 \mathrm{~nm}$, $342.247 \mathrm{~nm}$, and $379.639 \mathrm{~nm}$. Estimation of Gd in high purity Am solution using these analytical lines was found to be within the $\pm 5 \%$ range. This fact indicated the presence of Gd as an impurity in the high purity Am matrix since all spectral lines of Gd cannot be affected to the same extent. The same conclusions can be drawn for the values obtained in case of $\mathrm{Mg}$ at the $279.553 \mathrm{~nm}$ and $285.213 \mathrm{~nm}$ lines and $\mathrm{Cu}$ at the $213.598 \mathrm{~nm}$, $224.700 \mathrm{~nm}$, and $324.754 \mathrm{~nm}$ lines. Nevertheless, for $\mathrm{Cu}$ at the $283.26 \mathrm{~nm}$ line, there was a large increase in background. This was probably due to the wings of the most intense line 


\section{$\mathrm{A}_{\text {Somic }}^{\text {tomectroscopy }}$}

TABLE VI

Spectral Interference of Am on Other Analytes

\begin{tabular}{ccc}
\hline Element & $\lambda(\mathrm{nm})$ & $\begin{array}{c}100 \mu \mathrm{g} / \mathrm{mL} \\
\text { of } \mathrm{Am}\end{array}$ \\
\hline $\mathrm{Ag}$ & 328.068 & $\mathrm{BDL}$ \\
$\mathrm{Al}$ & 309.271 & $\mathrm{BDL}$ \\
$\mathrm{Ca}$ & 393.366 & $\mathrm{BDL}$ \\
$\mathrm{Cd}$ & 228.802 & $\mathrm{BDL}$ \\
$\mathrm{Co}$ & 238.892 & $\mathrm{BDL}$ \\
$\mathrm{Cr}$ & 283.563 & $\mathrm{BDL}$ \\
$\mathrm{Dy}$ & 353.170 & $\mathrm{BDL}$ \\
$\mathrm{Eu}$ & 420.505 & $\mathrm{BDL}$ \\
$\mathrm{Fe}$ & 259.940 & $\mathrm{BDL}$ \\
$\mathrm{Mn}$ & 257.610 & $\mathrm{BDL}$ \\
$\mathrm{Na}$ & 588.995 & $\mathrm{BDL}$ \\
$\mathrm{Ni}$ & 221.647 & $\mathrm{BDL}$ \\
$\mathrm{Pb}$ & 220.353 & $\mathrm{BDL}$ \\
$\mathrm{Sm}$ & 359.262 & $\mathrm{BDL}$ \\
$\mathrm{U}$ & 385.958 & $\mathrm{BDL}$ \\
\hline
\end{tabular}

BDL (background detection limit) = $<0.05 \mu \mathrm{g} / \mathrm{mL}$

of Am (283.236 nm). It can be inferred that in the presence of Am, $\mathrm{Cu}$ at the $283.260 \mathrm{~nm}$ line was highly interfered and should be avoided as an analytical line for $\mathrm{Cu}$ estimation.

\section{Validation of Methodology}

The determination of trace elements in nuclear materials (4-5,7-9) is an important feature of analytical chemistry in the nuclear field. For this purpose, ICP-AES-based techniques have been employed which requires chemical separation of $\mathrm{Pu}$. The analytical lines identified as free from spectral interference of Am were used subsequently for the ICP-AES determination of trace metals in Pu-based samples. Pu was separated using the well-known 30\% $\mathrm{TBP} / \mathrm{CCl}_{4} / 4 \mathrm{M} \mathrm{HNO}_{3}$ extraction procedure (24). To validate the methodology, synthetic samples

TABLE VII

Trace Elements Present in Purified Am

\begin{tabular}{lccc}
\hline Element & $\begin{array}{c}\lambda \\
(\mathrm{nm})\end{array}$ & $\begin{array}{c}\text { Concentration } \\
(\mu \mathrm{g} / \mathrm{mL})\end{array}$ & $\begin{array}{c}\text { Concentration } \\
(\mu \mathrm{g} / \mathrm{mL})\end{array}$ \\
\hline $\mathrm{Gd}$ & 310.050 & 0.98 & $1.03 \pm 0.05$ \\
& 335.048 & 1.01 & \\
& 342.247 & 1.12 & \\
& 379.639 & 1.02 & $0.38 \pm 0.02$ \\
\hline $\mathrm{Mg}$ & 279.553 & 0.40 & $0.38 \pm 0.06$ \\
$\mathrm{Zn}$ & 285.213 & 0.36 & $0.10 \pm 0.01$ \\
& 206.191 & 0.34 & \\
& 334.502 & 0.36 & \\
$\mathrm{Cu}$ & 213.856 & 0.44 & 0.11 \\
& 324.754 & 0.10 & 0.10 \\
& 213.598 & 396 This value is not included in the \\
& 224.700 & \multicolumn{2}{c}{ average for Cu. ${ }^{\mathrm{a}}$}
\end{tabular}

${ }^{a}$ The value obtained by monitoring $283.260 \mathrm{~nm} \mathrm{Cu}$ emission line is very high in contrast to those obtained using Cu emission 324.754, 213.598, and $224.700 \mathrm{~nm}$. This suggests that Am with its emission at $283.236 \mathrm{~nm}$ spectrally interfered at this wavelength for $\mathrm{Cu}$.

were prepared using high purity $\mathrm{PuO}_{2}$ (power reactor grade $\mathrm{Pu}$ ). A 5-g amount of $\mathrm{PuO}_{2}$ powder was dissolved in $\mathrm{HF}-\mathrm{HNO}_{3}$ mixture and the feed was adjusted to $3.5 \mathrm{M}$ $\mathrm{HNO}_{3}$. Five synthetic samples were prepared: Am blank (containing Am at $280 \mu \mathrm{g} / \mathrm{mL}$ ), Am blank spiked with $0.1 \mu \mathrm{g} / \mathrm{mL}, 1 \mu \mathrm{g} / \mathrm{mL}$ of critical elements (e.g.. B, Cd, Eu, Sm, Gd, Dy, Ag, etc., having lower specification limits for Pu-based fuel samples), and Am blank spiked with $0.5 \mu \mathrm{g} / \mathrm{mL}, 5 \mu \mathrm{g} / \mathrm{mL}$ of 18 common impurities. Seven contacts of $30 \%$ $\mathrm{TBP} / \mathrm{CCl}_{4}$ with aqueous:organic (1:1) were used for the removal of $\mathrm{Pu}$ from each synthetic sample. Quantitative removal of $\mathrm{Pu}$ was confirmed by radiometric analysis. All of these synthetic samples were analyzed for trace metals by ICPAES in addition to Am where both the analytical channels mentioned earlier of Am were used. The analytical results for the above-mentioned analytes with their specified analytical channels are given in Tables VIII and IX. From these data it was observed that the $\%$ recovery was within the acceptable limits for these elements.

This fact suggested that critical elements can be determined in the presence of $\sim 300 \mu \mathrm{g} / \mathrm{mL}$ Am at the $0.1 \mu \mathrm{g} / \mathrm{mL}$ level (Table VIII), whereas for common impurities, the level can be as low as $5 \mu \mathrm{g} / \mathrm{mL}$ (Table IX). The methodology developed in the present study can be used effectively for the ICP-AES determination of trace elements in Pu-based fuel samples containing sizeable amounts of Am. 
TABLE VIII

Determination of Critical Elements in Synthetic Samples of Pu Containing Sizeable Amounts of Am

\begin{tabular}{|c|c|c|c|c|c|c|c|c|c|}
\hline \multirow[t]{2}{*}{ Element } & \multirow{2}{*}{$\begin{array}{l}\text { Analytical } \\
\text { Line }\end{array}$} & \multicolumn{4}{|c|}{ Sample-1 } & \multicolumn{4}{|c|}{ Sample-2 } \\
\hline & & $\underset{\substack{\text { Alank } \\
(\mu \mathrm{g} / \mathrm{mL})}}{ }$ & $\begin{array}{l}\text { Amount } \\
\text { Added } \\
(\mu \mathrm{g} / \mathrm{mL})\end{array}$ & $\begin{array}{l}\text { Amount } \\
\text { Estimated } \\
(\mu \mathrm{g} / \mathrm{mL})\end{array}$ & $\begin{array}{c}\% \\
\text { Recovery }\end{array}$ & $\begin{array}{l}\text { Am } \\
\text { Blank } \\
(\mu \mathrm{g} / \mathrm{mL})\end{array}$ & $\begin{array}{l}\text { Amount } \\
\text { Added } \\
(\mu \mathrm{g} / \mathrm{mL})\end{array}$ & $\begin{array}{l}\text { Amount } \\
\text { Estimated } \\
(\mu \mathrm{g} / \mathrm{mL})\end{array}$ & $\begin{array}{c}\% \\
\text { Recovery }\end{array}$ \\
\hline Am & 283.236 & $280 \pm 10$ & - & $290 \pm 10$ & - & $280 \pm 10$ & - & $290 \pm 10$ & - \\
\hline Am & 408.930 & $280 \pm 10$ & - & $290 \pm 10$ & - & $280 \pm 10$ & - & $290 \pm 10$ & - \\
\hline Ag & 328.068 & $<0.05$ & 0.1 & 0.09 & 90 & $<0.05$ & 1 & 0.7 & 70 \\
\hline B & 249.773 & 0.18 & 0.1 & 0.30 & 120 & 0.18 & 1 & 0.28 & 100 \\
\hline $\mathrm{Be}$ & 313.042 & $<0.05$ & 0.1 & 0.1 & 100 & $<0.05$ & 1 & 1 & 100 \\
\hline $\mathrm{Cd}$ & 228.802 & $<0.05$ & 0.1 & 0.09 & 90 & $<0.05$ & 1 & 0.9 & 90 \\
\hline Dy & 353.170 & $<0.05$ & 0.1 & 0.1 & 100 & $<0.05$ & 1 & 0.9 & 90 \\
\hline $\mathrm{Eu}$ & 420.505 & $<0.05$ & 0.1 & 0.08 & 80 & $<0.05$ & 1 & 0.8 & 80 \\
\hline Gd & 342.247 & $<0.05$ & 0.1 & 0.08 & 80 & $<0.05$ & 1 & 0.9 & 90 \\
\hline $\mathrm{Sm}$ & 359.262 & $<0.05$ & 0.1 & 0.07 & 70 & $<0.05$ & 1 & 0.8 & 80 \\
\hline
\end{tabular}

TABLE X

Determination of Common Elements in Synthetic Samples of Pu Containing Sizeable Amounts of Am

\begin{tabular}{|c|c|c|c|c|c|c|c|c|c|}
\hline \multirow[t]{2}{*}{ Element } & \multirow{2}{*}{$\begin{array}{c}\text { Analytical } \\
\text { Line }\end{array}$} & \multicolumn{4}{|c|}{ Sample-3 } & \multicolumn{4}{|c|}{ Sample-4 } \\
\hline & & $\begin{array}{c}\text { Am } \\
\text { Blank } \\
(\mu \mathrm{g} / \mathrm{mL})\end{array}$ & $\begin{array}{l}\text { Amount } \\
\text { Added } \\
(\mu \mathrm{g} / \mathrm{mL})\end{array}$ & $\begin{array}{c}\text { Amount } \\
\text { Estimated } \\
(\mu \mathrm{g} / \mathrm{mL})\end{array}$ & $\begin{array}{c}\% \\
\text { Recovery }\end{array}$ & $\begin{array}{l}\text { Am } \\
\text { Blank } \\
(\mu \mathrm{g} / \mathrm{mL})\end{array}$ & $\begin{array}{l}\text { Amount } \\
\text { Added } \\
(\mu \mathrm{g} / \mathrm{mL})\end{array}$ & $\begin{array}{l}\text { Amount } \\
\text { Estimated } \\
(\mu \mathrm{g} / \mathrm{mL})\end{array}$ & $\begin{array}{c}\% \\
\text { Recovery }\end{array}$ \\
\hline Am & 283.236 & $280 \pm 10$ & - & $290 \pm 10$ & - & $280 \pm 10$ & - & $290 \pm 10$ & - \\
\hline $\mathrm{Am}$ & 408.930 & $280 \pm 10$ & - & $290 \pm 10$ & - & $280 \pm 10$ & - & $290 \pm 10$ & - \\
\hline $\mathrm{Al}$ & 309.271 & 1.7 & 0.5 & 2.1 & 80 & 1.9 & 5 & 6.9 & 100 \\
\hline $\mathrm{Ca}$ & 393.366 & 4 & 0.5 & 4.5 & 100 & 4 & 5 & 9.3 & 103 \\
\hline Co & 238.892 & $<0.05$ & 0.5 & 0.5 & 100 & $<0.05$ & 5 & 5.0 & 100 \\
\hline $\mathrm{Cr}$ & 283.563 & 0.3 & 0.5 & 0.75 & 90 & 0.3 & 5 & 5.4 & 102 \\
\hline $\mathrm{Cu}$ & 224.700 & 0.1 & 0.5 & 0.6 & 100 & 0.1 & 5 & 5 & 98 \\
\hline $\mathrm{Fe}$ & 259.940 & 2.2 & 0.5 & 2.7 & 100 & 2.2 & 5 & 7.4 & 104 \\
\hline $\mathrm{Ga}$ & 250.017 & 0.4 & 0.5 & 0.9 & 100 & 0.4 & 5 & 5.6 & 104 \\
\hline In & 303.936 & 0.2 & 0.5 & 0.7 & 100 & 0.2 & 5 & 5.2 & 100 \\
\hline $\mathrm{Mg}$ & 279.553 & 0.8 & 0.5 & 1.3 & 100 & 0.8 & 5 & 5.9 & 102 \\
\hline Mn & 257.610 & 0.1 & 0.5 & 0.6 & 100 & 0.1 & 5 & 5.3 & 104 \\
\hline Mo & 202.030 & 0.3 & 0.5 & 0.8 & 100 & 0.3 & 5 & 5.5 & 104 \\
\hline $\mathrm{Na}$ & 588.995 & 3.2 & 0.5 & 3.75 & 110 & 3.2 & 5 & 8.2 & 100 \\
\hline $\mathrm{Ni}$ & 221.647 & 0.2 & 0.5 & 0.7 & 100 & 0.2 & 5 & 5.2 & 100 \\
\hline $\mathrm{Pb}$ & 220.353 & 0.5 & 0.5 & 0.9 & 80 & 0.5 & 5 & 5.8 & 106 \\
\hline V & 309.311 & $<0.05$ & 0.5 & 0.5 & 100 & $<0.05$ & 5 & 5.1 & 102 \\
\hline W & 207.911 & 1.1 & 0.5 & 1.6 & 100 & 1.1 & 5 & 6.3 & 104 \\
\hline $\mathrm{Zn}$ & 213.856 & 2.9 & 0.5 & 3.35 & 90 & 2.9 & 5 & 8.0 & 102 \\
\hline
\end{tabular}




\section{CONCLUSION}

Plutonium (Pu) plays a key role in the development of atomic energy programs based on the closed-end nuclear fuel cycle. This involves reprocessing of the irradiated fuel and the use of reprocessed $\mathrm{Pu}$ in the fabrication of secondgeneration reactors as mixed oxide fuel. For quality control and quality assurance of nuclear fuels for second-generation reactors, it is necessary to determine the trace metal content in the nuclear fuel material. The americium (Am) concentraton associated with $\mathrm{Pu}$ depends on its burn-up and storage.

In the present work, a suitable methodology was developed for the determination of trace metallics in Pu-based fuel samples containing sizeable (up to $300 \mu \mathrm{g} / \mathrm{mL}$ ) amounts of Am. The analytical method involved chemical separation of $\mathrm{Pu}$ and analysis of the raffinate for trace metal determination by inductively coupled plasma atomic emission splectrometry (ICP-AES). Since Am associated with $\mathrm{Pu}$ is present in the raffinate, the investigations were carried out in order to understand the spectral interference from Am and to analyze the raffinate for Am by ICP-AES in the presence of concomitant trace elements.

These studies resulted in identifying the analytical lines for 25 trace metals free from spectral interference of Am using a spectrometer having a practical resolution of $0.005 \mathrm{~nm}$. For the estimation of Am, the analytical lines that are free from spectral interference of concomitant analytes were also identified. Using the ICP-AES technique, 25 trace elements along with Am were determined with a precision of $2 \%$ RSD. The method was validated by analyzing synthetic samples in the presence of $\sim 300 \mu \mathrm{g} / \mathrm{mL}$ of Am with a low detection limit in the range of $0.1 \mu \mathrm{g} / \mathrm{mL}$ for critical elements (B, Cd, Dy, Eu, Gd, Sm, etc.) and $5 \mu \mathrm{g} / \mathrm{mL}$ for other common impurities.

Received December 13, 2010.

\section{REFERENCES}

1. A. A. Argekar, M. J. Kulkarni, J. N. Mathur, and A. G. Page, Talanta 56, 591 (2002).

2. A.A. Argekar, J. N. Mathur. and A. G. Page, Anal. Chim. Acta 370, 163 (1998).

3. M.C. Edelson, F.L. De Kalb, R. K. Finge, and V.A. Fassel, Spectrochim. Acta, 41B, 475 (1986).

4. E. A. Huff and D.L. Bowers, Appl. Spectrosc. 43(2), 223 (1989).

5. R. Ko., Appl. Spectrosc. 38, 909 (1984).

6. C. Mahan, S. Bonchin, D. Figg, D. Gerth, and C. Collier., J. Anal. Spectrom. 15, 929 (2000).

7. M. Gopalkrishnan, K. Radhakrishnan, P. S. Dhami, V. T. Kulkarni, M. V. Joshi, A. B. Patwardhan, A. Ramanujam, and J. N. Mathur, Talanta 44, 169 (1997).

8. A. J. Johnson and E. Vuvoda, Anal. chem. 31, 1643 ( 1959)

9. C.H. Lee, M.Y. Suh, K.S. Choi, J.S Kim, B.C. Song, K.Y. Jee, and W.H Kim, Anal. Chim. Acta, 428, 133 (2001).

10. P.K. Mohapatra, V.C. Adya, S.K. Thulasidas, A. Bhattacharyya, Mithlesh Kumar, S.V. Godbole, and V.K. Manchanda, RACNT, BARC, Mumbai, 212 ( 2007).

11. B.A. Dhawale, B. Rajeswari, S.K. Thulasidas, A.G. Page, and M.D. Sastry, NUCAR 487 (2001).

12. X. Claudon, J.C. Birrolleau, M. Lavergne, B. Miche, and C Bergey, Spectrochim. Acta 42B, 407 (1987).

13. A. Mazzucotelli, F. De Paz, E. Magi, and R. Frache, Anal. Science 8, 189 (1992).

14. N. Daskalova, S. Velichkov, N. Krasnobaeva, and P. Slavova, Spectrochim. Acta 47B, E1595 (1992).

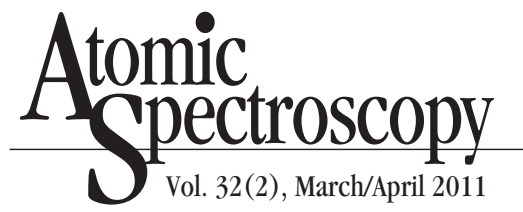

15. A. Sengupta, V.C. Adya, P.K. Mohapatra, S.V. Godbole, and V.K. Manchanda, J. Radioanal. Nucl. Chem. 283, 777 (2010).

16. F. Pilon, S. Lorthioir, J. C. Birolleau, and S. Lafontan J. Anal. At. Spectrom. 11, 759 (1996).

17. K. Yoshida and H Haraguchi, Anal. Chem. 56, 2580 (1984)

18. J.G. Crock, F.E. Litche, G.O. Riddle, and C.L. Beech, Talanta 33(7), 601 (1986).

19. W.S. Gardner, P.F. Landrum, and D.A. Yates, Anal. Chem. 54, 1196 (1982).

20. H.Ying, Z. Zhang, Z. Zhuang, P. Yang, X. Wang, B. Huang, and B. Li. Spectrochim. Acta 52B, 1567 (1997).

21. E.F. Worden, E.K. Hulet, and R.G. Gutmacher, Atomic Data and Nuclear Data Tables 18, 459 (1976).

22. Ultima JY ICP-AES User Manual.

23. V.C. Adya, A. Bhattacharyya, P.K Mohapatra, and V.K. Manchanda, SESTEC, BARC, Mumbai, India, 292 (2006).

24. S.K. Patil, V.V. Ramakrishna, G.V.N. Avadhany and M.V. Ramaniah, J. Inorg, Nucl. Chem., 35 2537 (1973). 